\title{
Superadded Coinfections and Antibiotic Resistance in the Context of COVID-19: Where do We Stand?
}

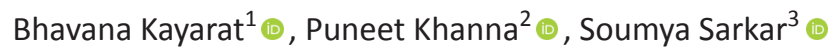

\begin{abstract}
Purpose of review: Poor outcomes in the current coronavirus disease 2019 (COVID-19) pandemic have been attributed to superadded bacterial coinfections. The World Health Organization has reported overzealous usage of broad-spectrum antibiotics during this current pandemic raising concerns of increasing antimicrobial resistance? Therefore, the knowledge of coinfection and the common pathogens during these challenging times is essential for antibiotic stewardship practices.

Recent findings: The incidence of reported superimposed bacterial and viral coinfections in COVID-19 patients is around 0.04 to $17 \%$. However, more than $70 \%$ of patients have received broad-spectrum antibiotics. The presence of a simultaneous coinfection can be suspected in patients with neutrophilic lymphocytosis and elevated procalcitonin in the setting of COVID-19. Multiplex polymerase chain reaction (PCR) panels, with its short turnaround time, aid in the definitive diagnosis of possible coinfection. Acinetobacter baumanii, Mycoplasma pneumonia, influenza virus, Aspergillus, Candida, etc., are commonly implicated pathogens.

Summary: Rapid characterization of coinfection and avoidance of overzealous use of broad-spectrum antibiotics in COVID-19 patients are the key to prevent antibiotic resistance during this pandemic.

Keywords: Antibiotic resistance, Coinfections, COVID-19_coronavirus disease 2019, SARS-CoV-2—severe acute respiratory syndrome coronavirus-2.

Indian Journal of Critical Care Medicine (2021): 10.5005/jp-journals-10071-23855
\end{abstract}

\section{INTRODUCTION}

Patients with respiratory viral infections are generally predisposed to bacterial coinfections. While a superinfection is attributed to resistant microorganisms or new-onset resistance to the previously used antibiotics, a coinfection is defined as an infection that occurs simultaneously with the initial agent. The difference is chiefly temporal.

The severe acute respiratory syndrome coronavirus 2 (SARS-CoV-2) disease is a global concern in view of endemicity, mortality, and an unprecedented burden on the current health-care system. SARS-CoV-2 is an enveloped, single-stranded RNA betacoronavirus. The clinical features mimic the previous outbreaks of SARS-CoV in 2002, and the Middle East respiratory syndrome coronavirus (MERS-CoV) in 2012. ${ }^{1}$

The prevalence of bacterial coinfections in the previous influenza epidemics ranges between 20 and 30\%., They usually occurred within the initial 6 days of influenza infection and were leagued with increased morbidity and mortality. The most common organism implicated during the influenza epidemic was Streptococcus pneumonia. ${ }^{4}$

Coinfections with Chlamydophilia pneumonia and Mycoplasma pneumonia have also been reported during the 2003 SARS- 1 epidemic. The incidence of coinfection was 4 to $25 \% .^{5}$ During the MERS-CoV outbreak, the coinfection rates were even lower ranging from 1 to $1.4 \%$. Atypical bacteria like Legionella pneumophilia, C. pneumoniae, and M. pneumoniae had been implicated. However, a study reported that treatment with macrolides did not improve the outcome in MERS-CoV patients with the said bacterial coinfections. $^{6}$

The majority of the studies in this current pandemic have focused primarily on SARS-CoV-2, while associations with coinfecting organisms have been comparatively overlooked. The

\begin{abstract}
${ }^{1-3}$ Department of Anaesthesiology, Pain Medicine and Critical Care, All India Institute of Medical Sciences, New Delhi, India

Corresponding Author: Soumya Sarkar, Department of Anaesthesiology, Pain Medicine and Critical Care, All India Institute of Medical Sciences, New Delhi, India, e-mail: drsoumyasarkar@yahoo.co.in

How to cite this article: Kayarat B, Khanna P, Sarkar S. Superadded Coinfections and Antibiotic Resistance in the Context of COVID-19: Where do We Stand? Indian J Crit Care Med 2021;25(6):699-703.

Source of support: Nil

Conflict of interest: None
\end{abstract}

extent to which SARS-CoV-2 is complicated by bacterial or fungal infections remains unclear. Envisioning the concerns of increased fatality of bacterial superinfections during previous influenza pandemics, pragmatic use of antibiotics in SARS-CoV-2 infection has been advocated. ${ }^{7,8}$. However, the incidence of coinfection in the previous coronavirus epidemics was much lower with little implications on mortality. Thus, overzealous use of antibiotics and consequently increasing bacterial resistance have become a serious concern. Therefore, the awareness about the usual organisms causing acute respiratory coinfection in patients already infected with SARS-CoV-2 is important for implementing antibiotic stewardship practices.

\section{Pathogenesis}

Studies on the influenza epidemic suggest that coinfection predominantly occurred during periods of high viral shedding within the first 6.2 (range, 1.3-11) days of infection. ${ }^{4}$ The susceptibility of the influenza virus to bacterial coinfections had been attributed 
to the viral enzyme neuraminidase and a proapoptotic influenza protein, PB-F2. ${ }^{9}$ As the viral replication accelerates, endothelial barrier disruption occurs leading to impaired alveolar-capillary oxygen transmission. Viral shedding is maximum from 7 days before to 3 days after symptom onset. ${ }^{10}$

The virus proliferation in the respiratory system affects the mucociliary clearance of bacteria from the lower airway. The deceased epithelial cells uncover the basal cell layer, resulting in bacterial adherence and invasion. The decrease of lymphocytes and host immune function further contribute. There is a delayed release of cytokines and chemokines from the respiratory epithelium, dendritic cells, and macrophages in patients with coronavirus disease 2019 (COVID-19). This hyperactive immune response, called the cytokine storm, is further worsened by coinfections or secondary infections. ${ }^{11}$

\section{Organisms}

Several studies have reported superadded bacterial, fungal, and even viral coinfections in COVID-19 patients (Table 1). A recent systematic review on 3,338 patients with COVID-19 has reported that $14.3 \%$ of patients are affected with secondary bacterial infection, and it is more common in critically ill patients. Mycoplasma, Haemophilus influenzae, and Pseudomonas aeruginosa are the most commonly reported organisms. ${ }^{12}$

Another meta-analysis in this regard has found $7 \%$ of hospitalized COVID-19 patients had a bacterial coinfection " $(95 \% \mathrm{Cl}$, $\left.3-12 \% ; n=2183 ; I^{2}=92.2 \%\right), "$ and $3 \%$ of them had a viral coinfection "(95\% Cl, 1-6; $\left.n=1014 ; I^{2}=62.3 \%\right)$." M. pneumoniae, $P$. aeruginosa, $H$. influenzae, and Klebsiella pneumoniae are the commonest bacteria, and respiratory syncytial virus and influenza $A$ are the commonest virus associated with. Fungal coinfection with Candida albicans, Aspergillus fumigatus, and flavus was also reported. ${ }^{13}$

\section{Clinical Presentations}

The presence of coinfection may lead to confounding and misleading diagnosis. Suspicion, identifying, and distinguishing them from colonization remain a challenge. COVID-19 is usually associated with lymphopenia. On the contrary, lymphocytosis has been reported in cases of coinfection with $M$. pneumonia. ${ }^{14}$ A possible bacterial coinfection can be suspected when patients present with neutrophilic lymphocytosis in the setting of COVID-19.

An increased level of procalcitonin has been associated with the severity of SARS-CoV-2 infection. It is identifiable in 2 to 4 hours, tops at 12 to 24 hours, with a half-life of 25 to 30 hours. ${ }^{15}$ Thus, the elevated procalcitonin level may be beneficial in identifying the presence of a superadded bacterial coinfection, as it is non specific and also raised in patients with end-stage renal disease, cardiogenic shock, and multiorgan failure. ${ }^{16}$

The computed tomography patterns of pneumonia are generally related to the pathogenesis of infection. In comparison to other viral pneumonia, COVID-19 tends to have a more peripheral distribution, lower lobe predominance, with rounded ground-glass opacities, increased vascular enlargement, and a "reverse halo" sign, central ground-glass opacities with an interrupted peripheral ring of consolidation. ${ }^{17}$ Bacterial or viral superinfection can complicate these findings. The presence of mediastinal lymphadenopathy, a tree in bud appearance, pleural effusion, cavitation, and pneumothorax should raise concern for probable coinfection. ${ }^{18,19}$
It is, however, difficult to determine the specific type and the number of coinfecting pathogens based on imaging findings and medical history alone. Therefore, for early and definitive diagnosis of associated coinfection and to detect a broad range of potential pathogens, multiplex polymerase chain reaction $(P C R)$ panels are required. They have a shorter turnaround time of 1 to 2 hours, higher sensitivity for viral pathogens, and help in the detection of a broad panel of a virus, and coinfections. ${ }^{20}$ The respiratory panel can spot 17 viruses and 3 bacteria simultaneously with an overall sensitivity and specificity of 95 and $99 \%$, respectively. The respiratory tract sample (tracheal aspirate, BAL, or sputum) can be collected as soon as COVID-19 is confirmed or when a coinfection is suspected, and the results will aid in initiating or de-escalating appropriate antibiotic therapy as indicated. Multiplex PCR panels have been used in earlier outbreaks of infective diarrhea and have been effective in detecting coinfections at a lesser time in comparison to conventional diagnostics. ${ }^{21}$

\section{IMPLICATIONS}

The clinical evidence so far shows that the bacterial, viral, or fungal coinfection rate of COVID-19 patients is lower than that of influenza viral infection. However, $70 \%$ of patients have received fluoroquinolones, third-generation cephalosporins, and other broad-spectrum antibiotics. ${ }^{22}$

Antibiotic prescriptions are becoming extensive and excessive during this pandemic, and $90 \%$ of patients are being prescribed empirical antibiotics. The World Health Organization has also reported widespread usage of azithromycin in the current scenario despite the absence of any clinical guidelines. Oral doxycycline is also being widely used for its spectrum against $M$. pneumonia and Staphylococcus aureus. ${ }^{22-24}$

At present, there is no consensus regarding the use of antibiotics in the background of COVID-19. While in China, broad-spectrum antibiotics covering all possible pathogens have been used in $>90 \%$ of patients, some countries abutted the use of antibiotics in mild to moderate SARS-CoV-2 patients (Table 2).

Antimicrobial resistance requires urgent attention and action. A survey conducted by the Infectious Disease International Research Initiative involving participants from 23 countries also revealed widespread broad-spectrum antibiotic use during this epidemic. ${ }^{25}$ Interruption of routine health services during the pandemic also has caused interruption to treatment, especially of tuberculosis and HIV which can further contribute to antimicrobial resistance. ${ }^{26}$ During the first SARS-CoV outbreak, the incidence of methicillin-resistant S. aureus (MRSA) significantly increased from $3.53 \%$ pre-SARS to $25.30 \%$ during the SARS outbreak. ${ }^{27}$

\section{ConClusion}

The ramification of COVID-19 on antimicrobial resistance remains unclear. In the absence of a definitive therapeutic and preventive modality, we should look ahead and prevent a larger hidden threat from rising upon us. Thus, further studies regarding the rapid characterization of coinfection and avoiding overzealous use of antibiotics in patients with mild to moderate COVID-19 are the need of the hour, keeping in mind the likelihood of secondary bacterial or fungal pneumonia in a patient with worsening respiratory failure or sepsis. 


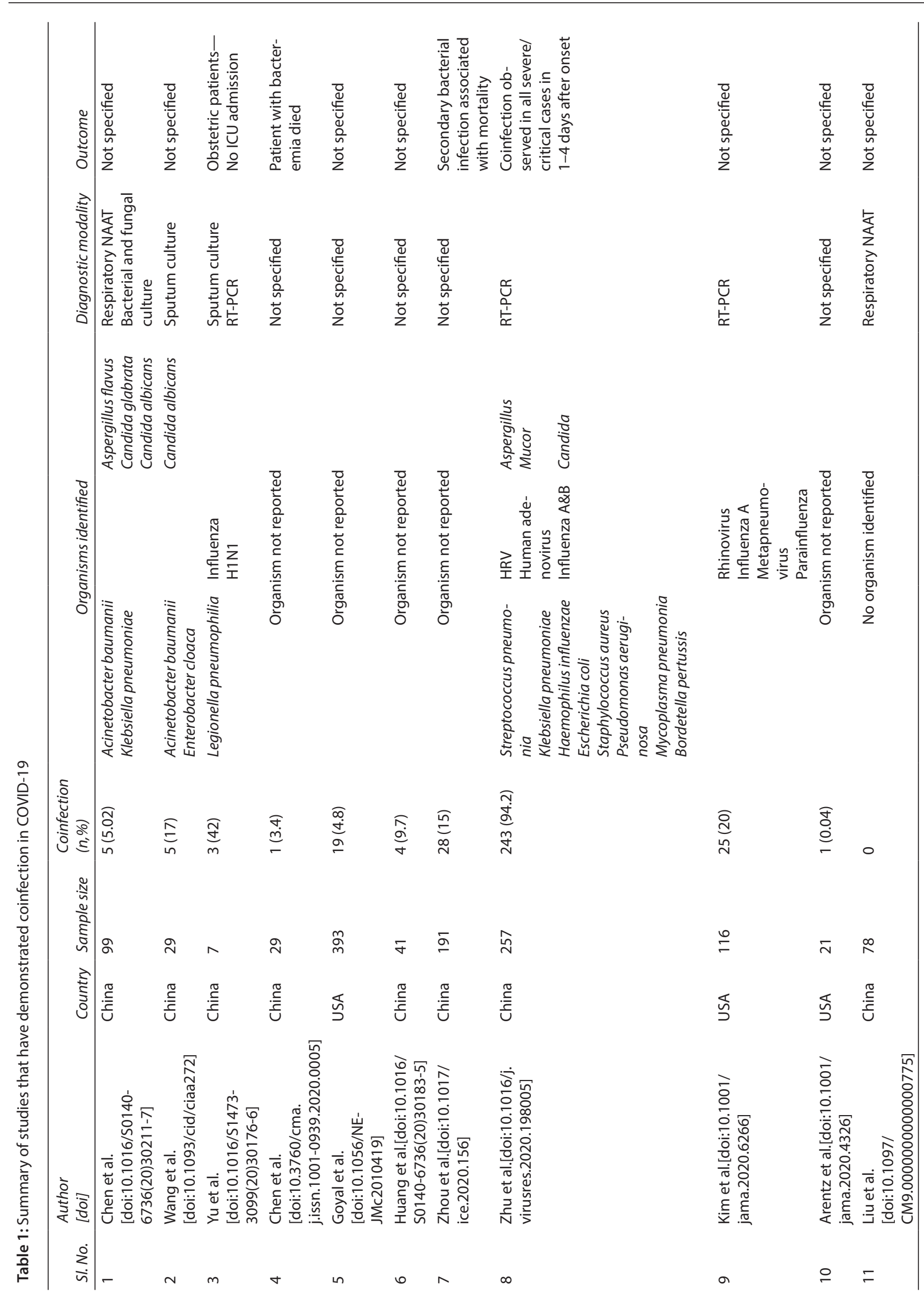


Table 2: Summary of the various society guidelines regarding antimicrobial therapy for coinfection in COVID-19

\begin{tabular}{|c|c|c|c|c|}
\hline SI. No. & Recommendation & $\begin{array}{l}\text { Diagnosis of coinfection and } \\
\text { guidance of antibiotic therapy }\end{array}$ & Treatment modality & Antimicrobial of choice \\
\hline 1 & $\begin{array}{l}\text { Surviving sepsis campaign } \\
\text { of critically ill adults [doi:10.1007/ } \\
\text { s00134-020-06022-5] }\end{array}$ & No recommendation & $\begin{array}{l}\text { Consider empiric antimi- } \\
\text { crobials in patients with } \\
\text { respiratory failure and } \\
\text { mechanically ventilated } \\
\text { patients (weak evidence) }\end{array}$ & No recommendation \\
\hline 2 & $\begin{array}{l}\text { NICE, UK [https://www.nice.org. } \\
\text { uk/guidance/ng173/ Assessing the } \\
\text { ongoing need for antibiotic] }\end{array}$ & $\begin{array}{l}\text { - Routine culture and sensitivity } \\
\text { (sputum, tracheal aspirate, blood) } \\
\text { - Chest imaging } \\
\text { - Full blood count } \\
\text { - Legionella and pneumococcal } \\
\quad \text { antigen (urine) } \\
\text { - Insufficient evidence for routine } \\
\text { procalcitonin testing }\end{array}$ & $\begin{array}{l}\text { Empirical antibiotics to } \\
\text { be started only on clinical } \\
\text { suspicion, and within } \\
4 \text { hrs of diagnosis }\end{array}$ & $\begin{array}{l}\text { Symptoms }<48 \text { hrs (suspected } \\
\text { CAP): } \\
\text { Oral: Doxycycline } 200 \mathrm{mg} \text { on } \\
\text { the first day and then } 100 \mathrm{mg} \\
\text { once a day } \\
\text { Intravenous: Co-amoxi- } \\
\text { clav } 1.2 \text { gm three times a } \\
\text { day + Clarithromycin } 500 \mathrm{mg} \\
\text { twice a day } \\
\text { Consider Levofloxacin } 500 \mathrm{mg} \\
\text { once/twice a day in severe } \\
\text { pneumonia } \\
\text { Symptoms }>48 \text { hrs (suspected } \\
\text { HAP): } \\
\text { Oral: Doxycycline } 200 \mathrm{mg} \text { on } \\
\text { first day and then } 100 \mathrm{mg} \\
\text { once a day } \\
\text { Intravenous: Piperacillin-Ta- } \\
\text { zobactam } 4.5 \text { gm three times } \\
\text { a day }\end{array}$ \\
\hline 3 & $\begin{array}{l}\text { MoHFW, India [https://www. } \\
\text { mohfw.gov.in/pdf/ClinicalManage- } \\
\text { mentProtocolforCOVID19.pdf] }\end{array}$ & No recommendation & $\begin{array}{l}\text { Antibiotics not to be } \\
\text { prescribed unless there } \\
\text { is a clinical suspicion of } \\
\text { bacterial infection }\end{array}$ & No recommendation \\
\hline 4 & $\begin{array}{l}\text { Infectious diseases Society of } \\
\text { America [www.idsociety.org/COV- } \\
\text { ID19 guidelines] }\end{array}$ & No recommendation & No recommendation & No recommendation \\
\hline 5 & $\begin{array}{l}\text { Canada [https://www.canada.ca/ } \\
\text { en/public-health/services/ } \\
\text { diseases/2019-novel- } \\
\text { coronavirus-infection/clinical- } \\
\text { management-covid-19.html\#8] }\end{array}$ & No recommendation & $\begin{array}{l}\text { Empirical antimicrobials } \\
\text { to treat all likely path- } \\
\text { ogens in patients with } \\
\text { sepsis and within } 1 \mathrm{hr} \text { of } \\
\text { diagnosis }\end{array}$ & No recommendation \\
\hline 6 & $\begin{array}{l}\text { Taiwan Clinical Guidance } \\
\text { [doi:10.1016/j.jmii.2018.11.004] }\end{array}$ & No recommendation & $\begin{array}{l}\text { Broad-spectrum } \\
\text { antibiotics covering all } \\
\text { possible pathogens are } \\
\text { suggested due to the } \\
\text { higher prevalence of } \\
\text { coinfections }\end{array}$ & $\begin{array}{l}\text { Mild: amoxicillin, azithromy- } \\
\text { cin, or fluoroquinolones } \\
\text { Moderate to severe: empirical } \\
\text { antibiotics to treat all possible } \\
\text { pathogens }\end{array}$ \\
\hline
\end{tabular}

\section{Author's Individual Contribution}

Dr. Bhavana Kayarat contributed to search strategy and draft the manuscript; Dr. Puneet Khanna contributed to conceptualization and editing; and Dr. Soumya Sarkar contributed to study selection, data extraction, draft the manuscript, and editing.

\section{ORCID}

Bhavana Kayarat 으 https://orcid.org/0000-0003-0964-2096

Puneet Khanna ๑ https://orcid.org/0000-0002-9243-9963

Soumya Sarkar (1) https://orcid.org/0000-0003-0497-9909

\section{References}

1. WassenaarTM, Zou Y. 2019_nCoV/SARS-CoV-2: rapid classification of betacoronaviruses and identification of Traditional Chinese Medicine as potential origin of zoonotic coronaviruses. Lett Appl Microbiol 2020;70(5):342-348. DOI: 10.1111/lam.13285.

2. Shah NS, Greenberg JA, McNulty MC, Gregg KS, Riddell J, Mangino JE, et al. Bacterial and viral co-infections complicating severe influenza: incidence and impact among 507 U.S. patients, 2013-14. J Clin Virol 2016;80:12-19. DOI: 10.1016/j.jcv.2016.04.008.

3. Klein EY, Monteforte B, Gupta A, Jiang W, May L, Hsieh YH, et al. The frequency of influenza and bacterial coinfection: a systematic review and meta-analysis. Influenza Other Respir Viruses 2016;10(5):394-403. DOI: 10.1111/irv.12398. 
4. Chertow DS, Memoli MJ. Bacterial coinfection in influenza: a grand rounds review. JAMA 2013;309(3):275-282. DOI: 10.1001/ jama.2012.194139.

5. Jang TN, Yeh DY, Shen SH, Huang CH, Jiang JS, Kao SJ. Severe acute respiratory syndrome in Taiwan: analysis of epidemiological characteristics in 29 cases. J Infect 2004;48(1):23-31. DOI: 10.1016/ j.jinf.2003.09.004.

6. Arabi YM, Deeb AM, Al-Hameed F, Mandourah Y, Almekhlafi GA, Sindi AA, et al. Macrolides in critically ill patients with Middle East Respiratory Syndrome. Int J Infect Dis 2019;81:184-190. DOI: 10.1016/ j.ijid.2019.01.041.

7. WHO guidance on clinical management of influenza infections. Available from: https://www.who.int/influenza/resources/documents/ clinical_management_2012/en/ [Accessed August 29, 2020].

8. Alhazzani W, Møller MH, Arabi YM, Loeb M, Gong MN, Fan E, et al. Surviving sepsis campaign: guidelines on the management of critically ill adults with coronavirus disease 2019 (COVID-19). Intensive Care Med 2020;46(5):854-887. DOI: 10.1007/s00134-020-06022-5.

9. Li N, Ren A, Wang X, Fan X, Zhao Y, Gao GF, et al. Influenza viral neuraminidase primes bacterial coinfection through TGF- $\beta$ mediated expression of host cell receptors. Proc Natl Acad Sci U S A 2015;112(1):238-243. DOI: 10.1073/pnas.1414422112.

10. He X, Lau EHY, Wu P, Deng X, Wang J, Hao X, et al. Temporal dynamics in viral shedding and transmissibility of COVID-19. Nat Med 2020;26(5):672-675. DOI: 10.1038/s41591-020-0869-5.

11. Ye Q, Wang B, Mao J. The pathogenesis and treatment of the 'Cytokine Storm' in COVID-19. J Infect 2020;80(6):607-613. DOI: 10.1016/ j.jinf.2020.03.037.

12. Langford BJ, So M, Raybardhan S, Leung V, Westwood D, MacFadden DR, et al. Bacterial co-infection and secondary infection in patients with COVID-19: a living rapid review and meta-analysis. Clin Microbiol Infect 2020;26(12):1622-1629. DOI: 10.1016/j. cmi.2020.07.016.

13. Lansbury L, Lim B, Baskaran V, Lim WS. Co-infections in people with COVID-19: a systematic review and meta-analysis. J Infect 2020;81(2):266-275. DOI: 10.1016/j.jinf.2020.05.046.

14. Fan BE, Lim KGE, Chong VCL, Chan SSW, Ong KH, Kuperan P. COVID-19 and mycoplasma pneumoniae coinfection. Am J Hematol 2020;95(6):723-724. DOI: 10.1002/ajh.25785.

15. Jin M, Khan Al. Procalcitonin: uses in the clinical laboratory for the diagnosis of sepsis. Lab Med 2010;41(3):173-177. DOI: 10.1309/ LMQ2GRR4QLFKHCH9.

16. Azzini AM, Dorizzi RM, Sette $\mathrm{P}$, Vecchi M, Coledan I, Righi E, et al. A 2020 review on the role of procalcitonin in different clinical settings: an update conducted with the tools of the Evidence Based Laboratory Medicine. Ann Transl Med 2020;8(9):610. DOI: 10.21037/atm-20-1855.
17. Yadav R, Sahoo D, Graham R. Thoracic imaging in COVID-19. Cleve Clin J Med 2020;87(8):469-476. DOI: 10.3949/ccjm.87a.ccc032.

18. Kanne JP, Little BP, Chung JH, Elicker BM, Ketai LH. Essentials for radiologists on COVID-19: an update-radiology scientific expert panel. Radiology 2020;296(2):E113-E114. DOI: 10.1148/ radiol.2020200527.

19. Rodrigues JCL, Hare SS, Edey A, Devaraj A, Jacob J, Johnstone A et al. An update on COVID-19 for the radiologist - a British society of Thoracic Imaging statement. Clin Radiol 2020;75(5):323-325. DOI: 10.1016/j.crad.2020.03.003.

20. Huang HS, Tsai CL, Chang J, Hsu TC, Lin S, Lee CC. Multiplex PCR system for the rapid diagnosis of respiratory virus infection: systematic review and meta-analysis. Clin Microbiol Infect 2018;24(10):10551063. DOI: 10.1016/j.cmi.2017.11.018.

21. Ramakrishnan B, Gopalakrishnan R, Senthur Nambi P, Durairajan SK, Madhumitha R, Tarigopula A, et al. Utility of multiplex polymerase chain reaction $(P C R)$ in diarrhea - an Indian perspective. Indian J Gastroenterol 2018;37(5):402-409. DOI: 10.1007/s12664-0180889-y.

22. Rawson TM, Moore LSP, Zhu N, Ranganathan N, Skolimowska K, Gilchrist $M$, et al. Bacterial and fungal coinfection in individuals with coronavirus: a rapid review to support COVID-19 antimicrobial prescribing. Clin Infect Dis 2020;71(9):2459-2468. DOI: 10.1093/cid/ ciaa530.23.

23. Lai CC, Wang CY, Hsueh PR. Co-infections among patients with COVID-19: the need for combination therapy with non-anti-SARSCoV-2 agents? J Microbiol Immunol Infect 2020;53(4):505-512. DOI: 10.1016/j.jmii.2020.05.013.

24. Vincent JL, Sakr Y, Singer M, Martin-Loeches I, MacHado FR, Marshall $J C$, et al. Prevalence and outcomes of infection among patients in intensive care units in 2017. JAMA 2020;323(15):1478-1487. DOI: 10.1001/jama.2020.2717.

25. Beović $B$, Doušak $M$, Ferreira-Coimbra J, Nadrah $K$, Rubulotta $F$ Belliato M, et al. Antibiotic use in patients with COVID-19: a 'snapshot' Infectious Diseases International Research Initiative (ID-IRI) survey. J Antimicrob Chemother 2020;75(11):3386-3390. DOI: 10.1093/jac/ dkaa326.

26. Prasad R, Singh A, Gupta N. Tuberculosis and COVID-19 in India: challenges and opportunities. Lung India 2020;37(4):292-294. DOI: 10.4103/lungindia.lungindia_260_20.

27. Yap FHY, Gomersall CD, Fung KSC, Ho PL, Ho OM, Lam PKN, et al. Increase in methicillin-resistant Staphylococcus aureus acquisition rate and change in pathogen pattern associated with an outbreak of severe acute respiratory syndrome. Clin Infect Dis 2004;39(4):511-516. DOI: $10.1086 / 422641$. 